\title{
Quality evaluation of parmesan-type cheese: a chemometric approach
}

\author{
Henrique JASTER ${ }^{1}$, Anna Carolina Leonelli Pires de CAMPOS ${ }^{1}$, Luciellen Bach AUER ${ }^{1}$, \\ Francine Gomes Basso LOS ${ }^{1}$, Renata Dinnies Santos SALEM ${ }^{2}$, Luís Antônio ESMERINO², \\ Alessandro NOGUEIRA ${ }^{2}$, Ivo Mottin DEMIATE2*
}

\begin{abstract}
Parmesan-type cheeses are the most consumed special cheeses in Brazil. It is generally sold in retail shops, either grated or in wedge-shaped pieces, and its quality varies considerably, which is reflected directly in its price. There is lack of processing standardization and, since the ripening period is fundamental for the quality of this hard, semi-fat cooked cheese, this stage seems to be the thin line between low and high quality products. It is important to note that the Italian Parmegiano Reggiano is matured for a period of twelve months, as well as its rival Grana Padano, and this long ripening period causes changes making them gourmet, highly-valued cheeses. In the present study, twelve different Parmesan-type cheeses were purchased from the Brazilian retail market and evaluated for microbiological, physicochemical, and instrumental parameters. Heterogeneous quality was confirmed by microbiological problems detected in the samples and physicochemical composition that did not meet current Brazilian specifications. The use of principal component analysis and hierarchical cluster analysis made it possible to separate the samples into three distinct groups, mainly due to different acidity and moisture levels, water activity, and hardness values. The price per $\mathrm{kg}$ was also considered and was correlated with moisture, acidity, and texture.
\end{abstract}

Keywords: cheese; microbiology; chemical composition; texture; PCA; HCA.

\section{Introduction}

Grana Padano and Parmigiano Reggiano (the latter is known as Parmesan in English) are quite similar Italian hard cheeses that have the reputation of being among the most typical products of the Italian agricultural/food industry (Bellesia et al., 2003). They are among the oldest cheeses in Europe, dating back to the 13th-14th century, and are also one of the most imitated agricultural products in the world (Zannoni, 2010). In 2012, the Italians produced 3,307,221 and 4,721,234 wheels of Parmigiano Reggiano and Grana Padano cheeses, respectively, weighing 38$39 \mathrm{~kg}$ each, with a trade value estimated in excess of 3.5 billion USD (Clal, 2013). The system associated with the production of Parmigiano Reggiano, the most important typical agricultural product in Italy, is an excellent example of rural development, involving artisanal labor and the production of a high quality food that is marketed worldwide (De Roest \& Menghi, 2000).

Italian Parmigiano Reggiano shows particular characteristics because it is produced by a consortium (Consorzio del Formaggio Parmigiano Reggiano) of small and medium sized cheese factories, mainly cooperatives, and it is made exclusively from raw and unheated bovine milk. It has a protected designation of origin (Itália, 1955; European Union, 2006) status within a limited geographic area in northern Italy (Zannoni, 2010; De Roest \& Menghi, 2000) and must follow traditional technologies, which include the feeding of the cows, several process details, and a long maturation period of 12 to 36 months (Bellesia et al., 2003). In the case of Parmigiano Reggiano, the use of any additive is strictly forbidden (Malacarne et al., 2009). Scientific information about the physicochemical composition, mechanisms of maturation, and the microbiological developments that may influence the volatile and non-volatile fractions are well defined in the literature (Barbieri et al., 1994; Barros et al., 2011; Gala et al., 2008; Langford et al., 2012; Monfredini et al., 2012; Panari et al., 2003).

In Brazil, in 2011, total cheese production reached 867,100 tons; production was estimated to exceed 1 million tons by 2013 (Scot Consultoria, 2013). Of this total production, Parmesantype cheese makes up more than 32,000 tons (Barros et al., 2011; Associação Brasileira das Indústrias de Queijos, 2010), representing $5.5 \%$ of the per capita consumption of $4 \mathrm{~kg} /$ year, which is still low if compared with that of neighboring Argentina (11.2 kg/year) (Castañeda et al., 2010). This hard cheese is the most popular among the so called 'special' cheeses that are available in the Brazilian market; it is available in 5-14 kg wheels and sold in wedge-shaped pieces or grated (Barros et al., 2011).

Brazilian Parmesan-type cheese may be produced from bovine raw milk, pasteurized milk, or reconstituted standardized milk (Brasil, 1997); its microbiological patterns are established in the Instrução Normativa 51 - IN 51 and Instrução Normativa 62 - IN 62, which regulates Brazilian milk production in terms of quality and identity (Brasil, 2002, 2011). Technically, Parmesan-type cheese is a hard, semi-fat, cooked, low moisture cheese with a tough and granular texture and a thick (4 to $8 \mathrm{~mm}$ ), smooth, straw-yellow crust. Sensory evaluations have

${ }^{1}$ Programa de Pós-Graduação em Ciência e Tecnologia de Alimentos, Universidade Estadual de Ponta Grossa - UEPG, Ponta Grossa, PR, Brasil

${ }^{2}$ Departamento de Engenharia de Alimentos, Universidade Estadual de Ponta Grossa - UEPG, Ponta Grossa, PR, Brasil, e-mail: demiate@gmail.com

${ }^{3}$ Departamento de Análises Clínicas e Toxicológicas, Universidade Estadual de Ponta Grossa - UEPG. Ponta Grossa, PR, Brasil

${ }^{*}$ Corresponding author 
characterized it as slightly spicy and salty with a mild and pleasant odor. Parmesan-type cheeses produced in Brazil have a cylindrical shape (wheels) weighing from 5 to $14 \mathrm{~kg}$; they are smaller than the Italian wheels that weigh around $40 \mathrm{~kg}$. The size and shape of the cheese wheels directly affects salt diffusion as well as several other physicochemical parameters. As a consequence, the development of the microbial communities associated with the cheese is affected (Monfredini et al., 2012). Processing yield is described as being around $13 \mathrm{~kg}$ of milk/ $\mathrm{kg}$ of cheese after the complete ripening period (Perry, 2004).

During processing, the coagulation temperature is $35^{\circ} \mathrm{C}$, and it reaches 52 to $54^{\circ} \mathrm{C}$ during cooking. Thermophilic lactic acid bacteria (LAB) (Lactobacillus helveticus and Streptococcus thermophilus) develop and remain viable after this stage inside the curd. Enzymatic activity catalyzes the conversion of milk carbohydrates, proteins, and lipids increasing the contents of lactate, peptides, and fatty acids that are involved in the typical sensory quality attributes of this cheese, which include texture, aroma, and taste (Monfredini et al., 2012; Kelly \& Fox, 2006; Lortal \& Chapot-Chartier, 2005).

$\mathrm{LAB}$ also compete with and inhibit the development of pathogenic bacteria and other undesirable microorganisms. Pyruvate conversion by the action of lactate dehydrogenase (LDH) results in lactate that decreases $\mathrm{pH}$ and acts favorably in the physicochemical stabilization of the product (Monfredini et al., 2012; Bromberg et al., 2004; Ogunbanwo et al., 2003). In Parmesan-type cheeses, ripening is carried out for around six months at a temperature that should not exceed $18{ }^{\circ} \mathrm{C}$ and a relative humidity of $80 \%$.

In Brazil, due to the lack of proper quality control and supervision by governmental agencies, the processing of Parmesan-type cheese does not follow a standardized protocol, which results in many different products being available in the national market, including those with a low quality, but which are nevertheless sold in large quantities due to low prices. Considering that a large percentage of this kind of hard cheese is available in grated form in the Brazilian market, the problem is even more complex; there have been reports of mixtures of different kinds of cheaper cheeses in the final product and even of the presence of starch in some commercial samples (Ribeiro et al., 2012). In the case of grated Parmesan-type cheese, the addition of up to $25 \%(\mathrm{~m} / \mathrm{m})$ of other kinds of dry cheeses is allowed in Brazil (Brasil, 1997; Trombete et al., 2012).

Chemometrics is a science of multidisciplinary nature which involves multivariate statistics, mathematical modeling, and information technology, specifically applied to chemical data (Cruz et al., 2013). Chemometric methods have been a useful tool in evaluating the quality and identity control of processing parameters for dairy products (Souza et al., 2011). Souza et al. (2011) applied PCA and HCA tools in a study on the presence of adulterants in Brazilian UHT milk. Cruz et al. (2013) used chemometrics methods to discriminate low-fat and full-fat yogurt characteristics. Karoui \& Baerdemaeker (2007), in a review paper, mentioned several studies using advanced analytical methods coupled with chemometric tools in dairy products, mainly with regard to cheese identification of authenticity of PDO, ripening period, and effects of different strain starters on the physicochemical results. These authors also cited studies on rheological properties of yogurts and butters using PCA and HCA, as well as the use of these tools with sensory data.

The aim of the present study was to evaluate the physicochemical, rheological, and microbiological quality of commercial Parmesan-type cheeses available in the Brazilian market using multivariate analysis for sample classification.

\section{Materials and methods}

\subsection{Materials}

Three samples of each of the twelve different brands of Parmesan-type cheeses found in supermarkets in the Campos Gerais Region, Paraná State, South Brazil, were purchased and evaluated. All chemicals used were of analytical grade, and the microbiological analyses were performed using available commercial culture media.

\subsection{Methods}

\section{Microbiological analysis}

The samples, which were randomly collected, were analyzed following the methodology of American Public Health Association - APHA (1992) and Silva et al. (2007), considering the parameters established by Brazilian legislation (Agência Nacional de Vigilância Sanitária, 2001). The most probable number (MPN) of coliforms at $35^{\circ} \mathrm{C}$ and at $45^{\circ} \mathrm{C}$ and Staphylococcus coagulase positive, aerobic mesophilic count and Salmonella sp. were determined.

\section{Physicochemical and instrumental analyses}

The potentiometric method was used to evaluate $\mathrm{pH}$; moisture content was measured gravimetrically after drying the samples in a laboratory oven at $102{ }^{\circ} \mathrm{C}$ to constant weight; ash content was also determined gravimetrically after the complete incineration of the samples in a muffle furnace (Fornos Jung, model 2310, Blumenau, SC, Brazil) at $525{ }^{\circ} \mathrm{C} / 6 \mathrm{~h}$ (Instituto Adolfo Lutz, 2008). Acidity was expressed as lactic acid (\%, $\mathrm{m} / \mathrm{m}$ ), as described by IAL (Instituto Adolfo Lutz, 2008). Lipid content was evaluated using a Gerber butyrometer especially developed for cheeses, and total nitrogen was measured by the Kjeldahl method with a conversion factor of 6.38 for crude protein (Association of Official Analytical Chemists, 1995).

The texture profile of the samples was evaluated by a TA.XT Plus Texture Analyzer (Stable Micro Systems, Godalming, Surrey, UK) using a P35 cylindrical probe. The samples were prepared as described by Bertolino et al. (2011); $2 \mathrm{~cm} \times 2 \mathrm{~cm}$ (diameter $\times$ height), compressed to $30 \%$ of original height at $0.8 \mathrm{~mm} / \mathrm{s}$ velocity, at $17^{\circ} \mathrm{C}$. The parameters evaluated were hardness, coesivity, adhesivity, elasticity, gumminess, chewiness, and resilience.

The color of the surface of the cheese was evaluated using an EZ MiniScan (Hunter Lab, Reston, Virginia, USA) colorimeter, 
considering the $L^{\star}, a^{*}$ and $b^{*}$ parameters. The results were expressed using the whiteness index (WI), according to Rocha et al. (2007), with white corresponding to 100.

Water activity was determined at $25^{\circ} \mathrm{C}$ using the Aqualab series 3 (model TE, Decagon Device, Pullman, WA, USA), according to Cichoski et al. (2008).

\section{Statistical analysis}

The data were presented as means \pm standard deviations. The results of the physicochemical and instrumental analyses were submitted to the Spearman correlation (Granato et al., 2014) $(\mathrm{p}<0.05)$ and also to chemometric methods, namely principal component analysis (PCA) and hierarchical cluster analysis (HCA) using STATISTICA 7.0 software (Stat Soft Inc., Tulsa, OK, USA). A data matrix was built adopting the results of physicochemical and instrumental parameters (color and texture profile) as columns and cheese samples as rows. PCA was adopted for grouping the samples according to the physicochemical and instrumental parameters (Alezandro et al., 2013). The considered eigenvalues were greater than 0.5, explaining the projection of the samples in the PC axes. Autoscaling was carried out for variance normalization among the variables. HCA was performed with autoscaled data. The similarities between the samples were calculated based on the square of the Euclidean distance, and the clusters were defined by the Ward hierarchic agglomeration method (Braga et al., 2013). In order to compare the results of the sample groups (Cluster 1, Cluster 2, and Cluster 3) found in the HCA, the data were initially evaluated using the Shapiro-Wilk test to prove normality, followed by the Levene test to prove variance homogeneity, and finally the Fisher test (when variance homogeneity was confirmed) or the Kruskall-Wallis test (when variance homogeneity was not confirmed) were applied. A level of $\mathrm{p}<0.05$ was considered significant.

\section{Results and discussion}

In the present study, coliforms growing at $45^{\circ} \mathrm{C}$ were found in $58.3 \%$ of the samples of Parmesan-type cheeses, and in $16.7 \%$ of these samples, this class of microorganism was confirmed. According to Brazilian legislation, the maximum tolerance for coliforms growing at $45^{\circ} \mathrm{C}$ is $5 \times 10^{2} / \mathrm{g}$ (Brasil, 1996). Samples coded as D and $\mathrm{E}$ had coliforms at $45^{\circ} \mathrm{C}$ above $10^{3} \mathrm{MPN} / \mathrm{g}$, i.e., above the maximum accepted level (Table 1). These are worrying levels and indicate unsatisfactory hygienic conditions associated with the studied samples. In the case of the Staphylococcus coagulase positive and Salmonela SP analyses, the results met the established standards (Table 1).

Salvador et al. (2001) studied the microbiological quality of Parmesan-type cheeses, and did not detect presence of coliforms at $45^{\circ} \mathrm{C}$ in grated samples; on the other hand, in the same study, the authors confirmed contamination by Staphylococcus aureus above the accepted level. Pimentel et al. (2002) did not find Salmonella sp, Staphylococcus coagulase positive or coliforms at $45^{\circ} \mathrm{C}$ in grated cheese samples. Barros et al. (2011) evaluated the hygienic quality of ripened Parmesan-type cheeses and reported average values $<1.0 \times 10^{0} \mathrm{MPN} / \mathrm{g}$ for total coliforms and Escherichia coli, but they did not detect Salmonella sp. The authors concluded that the samples analyzed were all in accordance with Brazilian legislation. Trombete et al. (2012) evaluated the chemical and microbiological quality of grated Parmesan-type cheeses from the city of Rio de Janeiro and reported that all the samples had Staphylococcus coagulase positive, with counts $<1.0 \times 10^{1} / \mathrm{g}$, and the absence of Salmonella sp; $6.7 \%$ of the samples were positive to coliforms at $35^{\circ} \mathrm{C}$ and at $45^{\circ} \mathrm{C}$, with thermotolerance counts of up to $4.0 \times 10^{1} / \mathrm{g}$, lower than the maximum value allowed by legislation. The presence of Escherichia coli was not confirmed in the samples.

In the present study, the plate count method was used to determine the total mesophilic aerobic cells the used to give a general indication of the total bacterial population present

Table 1. Microbiological evaluation of Parmesan-type cheese samples.

\begin{tabular}{|c|c|c|c|c|c|}
\hline Samples & $\begin{array}{c}\text { Total mesophilic count } \\
\text { (CFU/g) }\end{array}$ & $\begin{array}{l}\text { Coliforms } 45^{\circ} \mathrm{C} \\
\text { (MPN/g) }\end{array}$ & $\begin{array}{l}\text { Total coliforms } \\
\text { (MPN/g) }\end{array}$ & $\begin{array}{c}\text { Coagulase positive } \\
\text { Staphylococcus (CFU/g) }\end{array}$ & Salmonella sp/25g \\
\hline A & $1.6 \times 10^{3}$ & $<3.0$ & 11.0 & $<100$ & Absent \\
\hline B & $7.8 \times 10^{3}$ & $<3.0$ & 9.0 & $<100$ & Absent \\
\hline $\mathrm{D}$ & $5.0 \times 10^{1}$ & $1.1 \times 10^{3}$ & $>1.1 \times 10^{3}$ & $<100$ & Absent \\
\hline $\mathrm{E}$ & $9.0 \times 10^{3}$ & $>1.1 \times 10^{3}$ & $>1.1 \times 10^{3}$ & $<100$ & Absent \\
\hline $\mathrm{H}$ & $1.9 \times 10^{3}$ & $<3.0$ & $<3.0$ & $<100$ & Absent \\
\hline I & $4.7 \times 10^{2}$ & $<3.0$ & $<3.0$ & $<100$ & Absent \\
\hline $\mathrm{J}$ & $1.2 \times 10^{5}$ & $2.8 \times 10^{1}$ & $<3.0$ & $<100$ & Absent \\
\hline $\mathrm{K}$ & $1.8 \times 10^{4}$ & $1.5 \times 10^{1}$ & 7.0 & $<100$ & Absent \\
\hline $\mathrm{L}$ & $1.3 \times 10^{4}$ & $4.6 \times 10^{2}$ & $2.4 \times 10^{2}$ & $<100$ & Absent \\
\hline
\end{tabular}

*Parameter not included in Brazilian legislation (Agência Nacional de Vigilância Sanitária, 2001). 
in the Parmesan-type cheese samples. This technique is used to obtain general information about product quality, process control, manufacturing practices, raw material evaluation, and product shelf-life. Although Brazilian legislation (Brasil, 1996) does not require it, several studies include this microbiological count of mesophilic aerobes. In the present study, most of the samples had low counts, but the samples coded J and G showed high counts, of $1.2 \times 10^{5} \mathrm{CFU} / \mathrm{g}$ and $1.1 \times 10^{5} \mathrm{CFU} / \mathrm{g}$, respectively (Table 1 ).

The physicochemical results (Table 2) show that $41.6 \%$ of all of the studied samples were not in accordance with the Brazilian Technical Regulation of Parmesan Identity and Quality (Agência Nacional de Vigilância Sanitária, 2001; Brasil, 1996).

According to the Parmesan classification, maximum moisture content should be 35.9\% (Brasil, 1997, 1996). Among the studied samples, those coded as $\mathrm{A}$ and $\mathrm{C}$ had higher moisture levels, 41.5 and $38.1 \%$, respectively. Sample A also had the highest $\mathrm{pH}$ value (5.76), whereas sample $\mathrm{K}$ had the lowest $\mathrm{pH}$ (5.23).

It was also observed that sample $\mathrm{A}$ had the highest protein content (42.3\%), and sample $\mathrm{K}$ had the lowest protein content $(29.06 \%)$ and the lowest water activity $\left(\mathrm{A}_{\mathrm{w}}\right), 0.83$.

Regarding the levels of lipids (Table 2), the percentage in the dry extract for sample A $(22.8 \%)$ was lower than the values permitted by Brazilian legislation (25 to $44.9 \%$ ), whereas samples $\mathrm{C}$, E, I and K, had levels above the maximum; sample $\mathrm{C}$ had the highest lipid content (50.6\%).

Acidity, expressed in lactic acid, ranged from 0.17 to $0.44 \%$ $(\mathrm{m} / \mathrm{m})$. The ash content of the samples ranged from 4.49 to $6.36 \%$.

Sample A had the highest values of $\mathrm{pH}, \mathrm{A}_{\mathrm{w}}$ moisture and protein and the lowest values of lipid content (Table 2). Sample A also had the highest values for the instrumental texture parameters of hardness, gumminess and chewiness (Table 3). Sample C showed the highest values for elasticity, cohesiveness, and resilience (Table 3); and it also showed the highest fat content, which may have influenced the texture parameters.

The price of one kilogram (Brazilian $\mathrm{R} \$$ ) of the cheeses evaluated varied greatly; the cheapest was sample $C$, whereas samples D, E, and F were the most expensive (Table 2).

As expected, all values of the instrumental texture analysis were correlated (Table 4) and the highest hardness values were related to cheeses that were ripened for a longer period. Ripening involves several complex changes inside the cheese wheels, but water loss is also significant due to the humidity and temperature of the ripening chambers.

The titrable acidity of the samples did not strictly follow the $\mathrm{pH}$ values, as might have been expected; however, as reported by Hosken and Furtado (1983), this is perfectly normal due to high protein content, which exerts a buffering effect in cheeses. Another important factor is the salt content of the product, which can also dissolve protein fractions; some of the solubilized compounds can also be titrated such as organic acids.

With the onset of ripening, both lipolysis and proteolysis occur, with an increase in the level of free fatty and amino-acids (Macedo et al., 1996). A negative correlation was observed between protein and lipid contents $(\rho=-0.699, p=0.015)$. The hardness of the cheese samples was negatively correlated ( $\rho=-0.650, p=0.026$ ) with their water activities, indicating that the harder cheeses were drier; possibly due to dehydration during the ripening period. In general, this kind of cheese is ripened in chambers adjusted at temperatures of $18{ }^{\circ} \mathrm{C}$ (or less) and relative humidity of $85 \%$, which are considered low if compared to the humidity used in chambers to ripen other classes of cheeses.

As expected, water activity and moisture content were positively correlated $(\rho=0.769, p=0.005)$. The harder samples had lower moisture content and water activities; price $/ \mathrm{kg}$ had a positive correlation with the acidity level $(\rho=0.759, \mathrm{p}=0.005)$, probably due to the longer ripening period of the samples.

Table 2. Physicochemical quality of Parmesan-type cheese samples (mean \pm standard deviation).

\begin{tabular}{cccccccccc}
\hline Sample & Price $/ \mathrm{kg}(\mathrm{R} \$)$ & $\mathrm{pH}$ & Moisture \% & Ash \% & Acidity \% & WI & Aw & Protein \% & FDE \% \\
\hline A & 45.98 & $5.76 \pm 0.01$ & $41.54 \pm 0.79$ & $6.14 \pm 0.11$ & $0.23 \pm 0.02$ & $57.63 \pm 0.62$ & $0.94 \pm 0.10$ & $42.34 \pm 0.67$ & $22.80 \pm 1.07$ \\
B & 57.88 & $5.40 \pm 0.01$ & $32.97 \pm 0.41$ & $4.64 \pm 0.13$ & $0.29 \pm 0.02$ & $55.52 \pm 0.64$ & $0.90 \pm 0.10$ & $35.36 \pm 0.42$ & $40.03 \pm 1.25$ \\
C & 23.62 & $5.34 \pm 0.01$ & $38.12 \pm 0.43$ & $4.65 \pm 0.10$ & $0.17 \pm 0.01$ & $64.69 \pm 0.71$ & $0.94 \pm 0.10$ & $26.72 \pm 0.49$ & $50.63 \pm 1.28$ \\
D & 80.27 & $5.33 \pm 0.01$ & $28.46 \pm 0.37$ & $5.48 \pm 0.11$ & $0.42 \pm 0.04$ & $61.24 \pm 0.52$ & $0.86 \pm 0.10$ & $30.66 \pm 0.38$ & $44.73 \pm 1.17$ \\
E & 73.60 & $5.42 \pm 0.01$ & $29.93 \pm 0.32$ & $4.75 \pm 0.13$ & $0.44 \pm 0.03$ & $63.76 \pm 0.54$ & $0.87 \pm 0.11$ & $35.84 \pm 0.46$ & $46.85 \pm 1.12$ \\
F & 67.19 & $5.50 \pm 0.01$ & $32.39 \pm 0.43$ & $4.49 \pm 0.11$ & $0.36 \pm 0.03$ & $66.97 \pm 0.53$ & $0.88 \pm 0.10$ & $32.19 \pm 0.55$ & $43.63 \pm 1.05$ \\
G & 48.75 & $5.35 \pm 0.01$ & $31.65 \pm 0.38$ & $4.83 \pm 0.10$ & $0.31 \pm 0.02$ & $58.85 \pm 0.51$ & $0.90 \pm 0.11$ & $29.30 \pm 0.47$ & $44.87 \pm 0.16$ \\
H & 49.95 & $5.23 \pm 0.01$ & $28.82 \pm 0.32$ & $5.52 \pm 0.10$ & $0.33 \pm 0.02$ & $61.33 \pm 0.48$ & $0.88 \pm 0.12$ & $30.22 \pm 0.48$ & $44.02 \pm 1.22$ \\
I & 57.50 & $5.52 \pm 0.01$ & $30.19 \pm 0.31$ & $4.47 \pm 0.12$ & $0.31 \pm 0.01$ & $64.71 \pm 0.53$ & $0.89 \pm 0.11$ & $30.11 \pm 0.44$ & $46.08 \pm 1.01$ \\
J & 44.98 & $5.35 \pm 0.01$ & $33.68 \pm 0.27$ & $4.49 \pm 0.13$ & $0.33 \pm 0.01$ & $62.08 \pm 0.55$ & $0.87 \pm 0.10$ & $31.10 \pm 0.49$ & $40.97 \pm 1.13$ \\
K & 49.10 & $5.44 \pm 0.01$ & $27.50 \pm 0.31$ & $6.36 \pm 0.17$ & $0.31 \pm 0.02$ & $63.61 \pm 0.58$ & $0.83 \pm 0.10^{\mathrm{f}}$ & $29.06 \pm 0.57$ & $49.20 \pm 1.29$ \\
L & 40.44 & $5.64 \pm 0.01$ & $33.88 \pm 0.32$ & $5.39 \pm 0.11$ & $0.27 \pm 0.01$ & $66.10 \pm 0.57$ & $0.89 \pm 0.11$ & $31.91 \pm 0.62$ & $38.57 \pm 0.99$ \\
$p-$ & & & & & & & & \\
value $^{1}$ & 0.0002 & 0.0003 & 0.0012 & 0.0034 & 0.0006 & 0.0013 & $<0.0001$ & 0.0040 \\
\hline
\end{tabular}

FDE = fat in dry extract; ${ }^{1}$ one-way ANOVA or Kruskal-Wallis test. 
Table 3. Texture profile analysis (TPA) of Parmesan-type cheese samples.

\begin{tabular}{|c|c|c|c|c|c|c|c|}
\hline Sample & Hardness (g) & Adhesivity (g.s) & Elasticity $(\mathrm{mm})$ & Cohesiveness & Gumminess ${ }^{\star}$ & Chewiness (g.mm) & Resilience $^{*}$ \\
\hline $\mathrm{A}$ & $2,522.81$ & -2.48 & 0.75 & 0.74 & $1,861.11$ & $1,400.15$ & 0.36 \\
\hline B & $9,268.41$ & -2.43 & 0.80 & 0.68 & $6,595.98$ & $5,299.44$ & 0.33 \\
\hline $\mathrm{C}$ & $3,657.11$ & -6.24 & 0.86 & 0.79 & $2,902.63$ & $2,514.29$ & 0.44 \\
\hline $\mathrm{D}$ & $6,325.98$ & -3.21 & 0.60 & 0.52 & $3,353.47$ & $2,054.54$ & 0.21 \\
\hline $\mathrm{E}$ & $8,506.02$ & -3.16 & 0.78 & 0.53 & $4,511.55$ & $3,504.84$ & 0.22 \\
\hline $\mathrm{F}$ & $6,873.11$ & -3.14 & 0.77 & 0.35 & $2,439.89$ & $1,880.33$ & 0.17 \\
\hline G & $6,551.73$ & -1.47 & 0.84 & 0.76 & $5,021.49$ & $4,249.91$ & 0.38 \\
\hline $\mathrm{H}$ & $8,441.07$ & -0.71 & 0.85 & 0.80 & $6,770.71$ & $5,787.67$ & 0.44 \\
\hline I & $5,723.92$ & -1.78 & 0.79 & 0.75 & $4,354.45$ & $3,481.02$ & 0.37 \\
\hline $\mathrm{J}$ & $9,374.05$ & -1.93 & 0.80 & 0.70 & $6,684.99$ & $5,398.96$ & 0.33 \\
\hline K & $11,471.69$ & -0.65 & 0.80 & 0.65 & $7,869.50$ & $6,336.98$ & 0.29 \\
\hline $\mathrm{L}$ & $7,779.54$ & -0.59 & 0.83 & 0.77 & $6,028.80$ & $5,053.97$ & 0.40 \\
\hline$p$-value ${ }^{1}$ & 0.006 & 0.038 & 0.004 & 0.003 & 0.004 & 0.004 & 0.001 \\
\hline
\end{tabular}

*adimensional. ${ }^{1}$ Kruskal-Wallis.

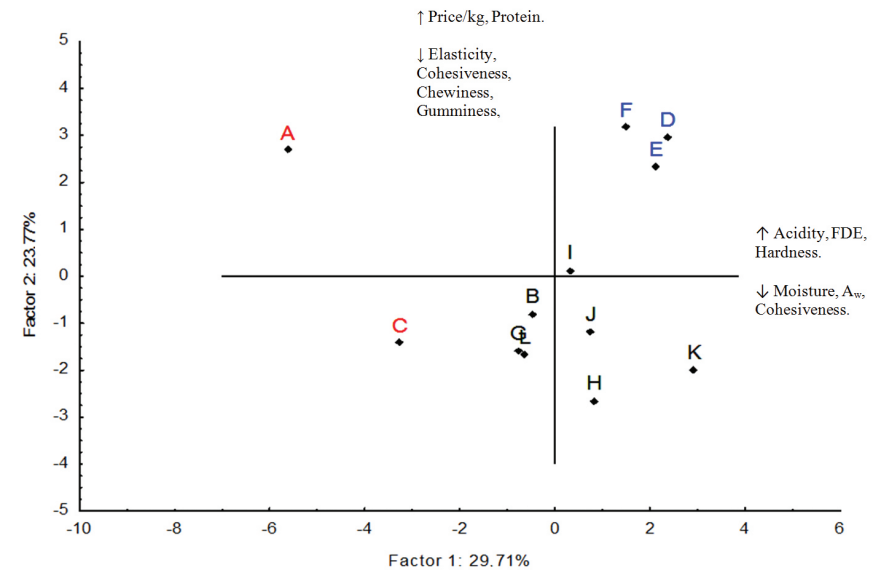

Figure 1. PCA applied to commercial Parmesan-type cheese samples.

PCA was carried out to verify the behavior of the samples in terms of the quality analyses and their 2D distribution (PC1 $\times$ PC2), which explained $53.48 \%$ of the data variability, as shown in Figure 1. The first PC discriminated the samples according to higher acidity, fat, hardness, lower moisture, Aw, cohesiveness, and resilience. The second PC separated the samples in relation to higher price and protein content and lower elasticity and chewiness. In Figure 1, it is possible to observe that samples $\mathrm{A}$ and $\mathrm{C}$ became isolated from the two groups due to the fact that these two samples had the highest moisture and Aw values. Samples D, E and F remained grouped together, probably due to their higher prices $/ \mathrm{kg}$ and also their higher acidity values.

In terms of HCA, the same three groups remained as expected (Figure 2).

The clusters shown in Figure 2 were statistically different $(\mathrm{p}<0.05)$ (Table 5). Cluster 1 , which includes samples A and $\mathrm{C}$, was named as "Low value, low quality" because it had presented the highest values of moisture content, water activity,

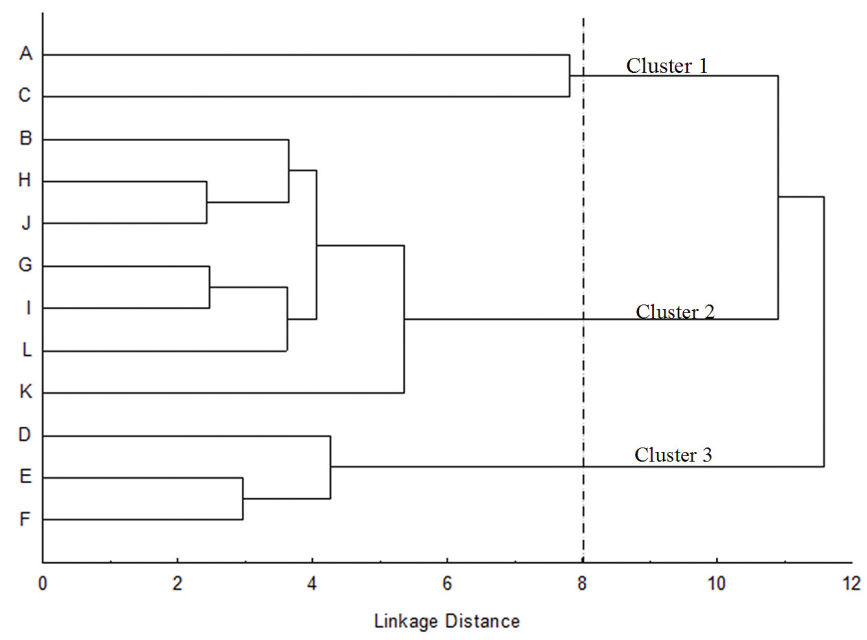

Figure 2. HCA applied to commercial Parmesan-type cheese samples.

cohesiveness, and resilience, low acidity values, and lower prices/ $\mathrm{kg}$ if compared with those of the other samples. Cluster 3, on the other hand, grouped the samples with higher prices $/ \mathrm{kg}$ and acidity level, as well as higher values for hardness could be named as "Hihg value, high quality", in contrast with the samples in Cluster 1. Cluster 2 grouped the samples with intermediary characteristics when compared to those of Clusters 1 and 3 . This cluster, named as "Intermediate value, high quality" has the average characteristics expected for Parmesan-type cheese, i.e., low moisture, low aW, and hardness statistically similar to those of Cluster 3, but they had statistical differences in price and acidity level. It is important to point out that among the samples studied, there was only one that was imported from Italy (Grana Padano, PDO); and this sample was grouped in Cluster 2, confirming the high quality of these group. In this sense, Cluster 2 can be considered the one that grouped the samples with the most desirable characteristics in relation to Italian Parmesan cheese. 


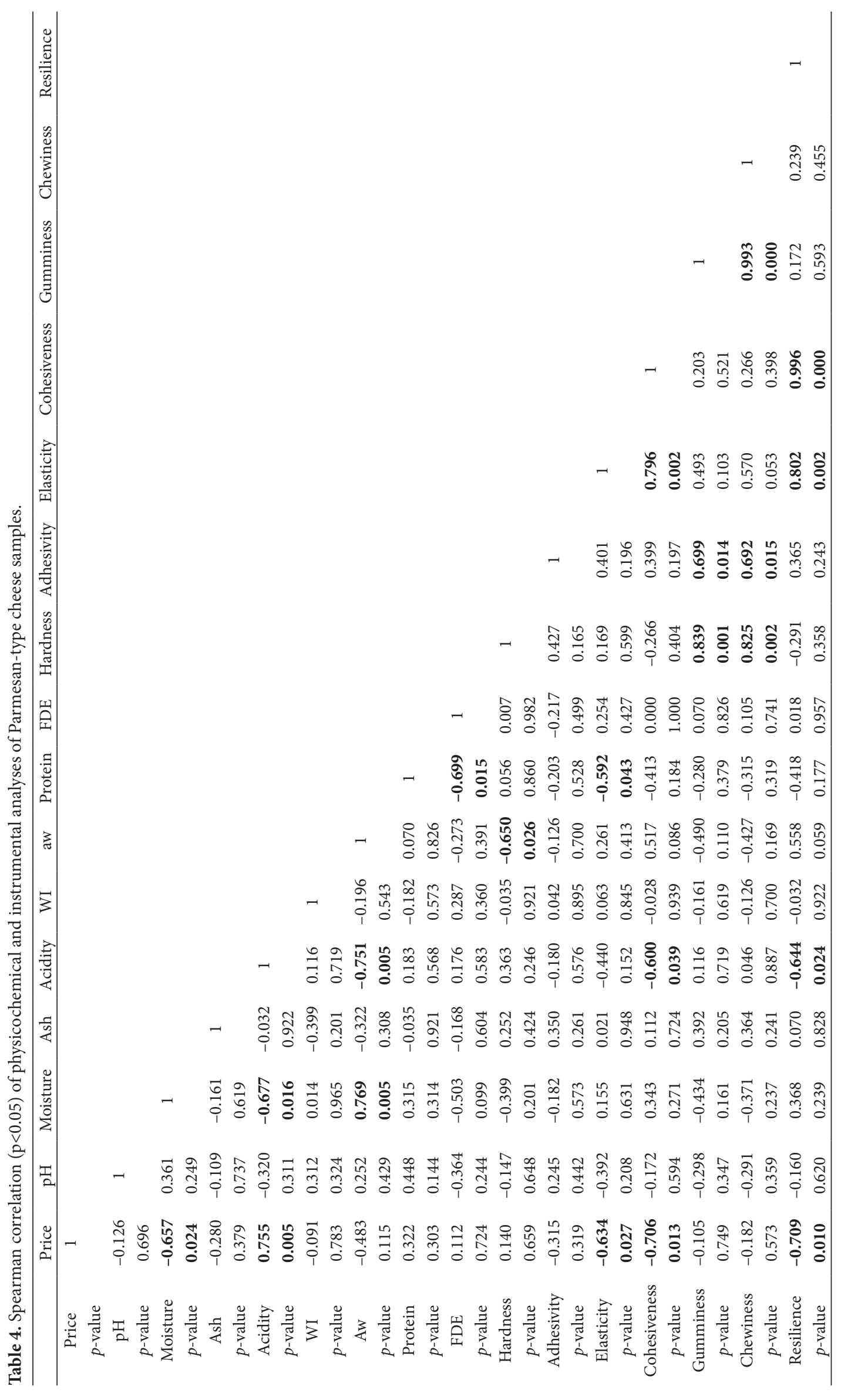


Table 5. Average values and standard deviations of Clusters 1, 2, and 3 in relation to the studied parameters for Parmesan-type cheeses.

\begin{tabular}{|c|c|c|c|c|c|c|}
\hline Variable & $\begin{array}{c}\text { Cluster } 1 \\
\text { (Low value, } \\
\text { low quality } n=2 \text { ) }\end{array}$ & $\begin{array}{c}\text { Cluster } 2 \\
\text { (Intermediate value, } \\
\text { high quality } \mathrm{n}=7 \text { ) }\end{array}$ & $\begin{array}{c}\text { Cluster } 3 \\
\text { (High value, } \\
\text { high quality } \mathrm{n}=3 \text { ) }\end{array}$ & pANOVA & pLevene & $\mathrm{PSD}^{*}$ \\
\hline Price/kg & $34.80^{c}$ & $49.80^{b}$ & $73.69^{a}$ & 0.001 & 0.113 & 15.344 \\
\hline Moisture & $39.83^{a}$ & $31.24^{\mathrm{b}}$ & $30.26^{\mathrm{b}}$ & 0.003 & 0.653 & 4.093 \\
\hline Ash & 5.40 & 5.24 & 4.91 & 0.700 & 0.443 & 0.641 \\
\hline Acidity & $0.20^{c}$ & $0.31^{\mathrm{b}}$ & $0.41^{\mathrm{a}}$ & $<0.001$ & 0.210 & 0.074 \\
\hline$A_{w}$ & $0.94^{\mathrm{a}}$ & $0.88^{\mathrm{b}}$ & $0.87^{\mathrm{b}}$ & 0.014 & 0.297 & 0.032 \\
\hline Protein & 34.53 & 31.01 & 32.90 & 0.461 & $<0.001$ & 4.113 \\
\hline FDE & 36.72 & 43.39 & 45.07 & 0.892 & $<0.001$ & 7.189 \\
\hline Hardness & $3089.96^{\mathrm{b}}$ & $8372.92^{\mathrm{a}}$ & $7235.04^{\mathrm{a}}$ & 0.011 & 0.440 & 2499.658 \\
\hline Adhesivity & $-4.36^{\mathrm{b}}$ & $-1.37^{\mathrm{a}}$ & $3.17^{\mathrm{b}}$ & 0.018 & $<0.001$ & 1.570 \\
\hline Resilience & $0.40^{\mathrm{a}}$ & $0.36^{\mathrm{a}}$ & $0.20^{\mathrm{b}}$ & 0.001 & 0.441 & 0.089 \\
\hline
\end{tabular}

$\mathrm{a}, \mathrm{b}, \mathrm{c}$ - Different letters in the same row mean significant differences by the Fisher or Kruskall-Wallis tests. pANOVA: analysis of variance, pLevene: analysis of homogeneity of variance. ${ }^{*}$ PSD: pooled standard deviation.

\section{Conclusion}

Parmesan-type cheeses available in the Brazilian market showed heterogeneous quality, and the main differences were found in their lipid and moisture contents and in the acidity level. These differences directly influenced the price $/ \mathrm{kg}$, indicating the lack of quality standardization of this kind of cheese, which was probably associated with processing differences as well as with ripening conditions and ripening period. Cluster analysis and principal components analysis were successfully used for the classification of these samples.

\section{Acknowledgements}

The authors are deeply grateful to CAPES, FINEP and $\mathrm{CNPq}$ for the financial support and for the research scholarships granted. Alessandro Nogueira and Ivo Mottin Demiate are $\mathrm{CNPq}$ research fellows.

\section{References}

Agência Nacional de Vigilância Sanitária - ANVISA. (2001). Aprova regulamento técnico sobre os padrões microbiológicos de alimentos, em anexo (Resolução RDC no 12, de 02 de janeiro de 2001). Diário Oficial da República Federativa do Brasil.

Alezandro, M., Granato, D., \& Genovese, M. (2013). Jaboticaba (Myrciaria jaboticaba (Vell.)Berg), a Brazilian grape-like fruit, improves plasma lipid profile in streptozotocin-mediated oxidative stress in diabetic rats. Food Research International, 54, 650-659. http://dx.doi.org/10.1016/j.foodres.2013.10.024

American Public Health Association - APHA. (1992). Standard methods for the examination of dairy products (16th ed.). Washington: APHA.

Associação Brasileira das Indústrias de Queijos - ABIQ. (2010). Queijos - Mercado total brasileiro. ABIQ.

Association of Official Analytical Chemists - AOAC. (1995). Official methods of analysis of AOAC international. Washington: AOAC.
Association of Official Analytical Chemists - AOAC. (1995). Official methods of analysis of AOAC international. Washington: AOAC.

Barbieri, G., Bolzoni, L., Careri, M., Mangia, A., Parolari, G., Spagnoli, S., \& Virgili, R. (1994). Study of the Volatile Fraction of Parmesan Cheese. Journal of Agricultural and Food Chemistry, 42(5), 1170-6. http://dx.doi.org/10.1021/jf00041a023

Barros, J. J. C., Azevedo, A. C., Faleiros Júnior, L. R., Taboga, S. R., \& Penna, A. L. B. (2011). Queijo Parmesão: caracterização físicoquímica, microbiológica e microestrutura. Ciência e Tecnologia de Alimentos, 31(2), 285-94. http://dx.doi.org/10.1590/S010120612011000200002

Bellesia, F., Pinetti, A., Pagnoni, U. M., Rinaldi, R., Zucchi, C., Caglioti, L., \& Palyi, G. (2003). Volatile components of Grana ParmigianoReggiano type hard cheese. Food Chemistry, 83, 55-61. http://dx.doi. org/10.1016/S0308-8146(03)00037-2

Bertolino, M., Dolci, P., Giordano, M., Rolle, L., \& Zeppa, G. (2011). Evolution of chemico-physical characteristics during manufacture and ripening of Castelmagno PDO cheese in wintertime. Food Chemistry, 129, 1001-11. http://dx.doi.org/10.1016/j. foodchem.2011.05.060

Braga, C., Granato, D., Zielinski, A., Silva, K., \& Nogueira, A. (2013). Classification of juices and fermented beverages made from unripe, ripe and senescent apples based on the aromatic profile using chemometrics. Food Chemistry, 141, 967-974. http://dx.doi. org/10.1016/j.foodchem.2013.04.007

Brasil. Ministério da Agricultura, Pecuária e Abastecimento. (1996). Aprova os Regulamentos Técnicos de identidade e qualidade dos produtos lácteos (Portaria no 146, de 7 de março de 1996). Diário Oficial da República Federativa do Brasil.

Brasil. Ministério da Agricultura, Pecuária e Abastecimento. (1997). Aprova o Regulamento Técnico Para Fixação de Identidade e Qualidade do Queijo Parmesão, Parmesano, Sbrinz, Reggiano e Reggianito (Portaria no 353, de 04 de setembro de 1997). Diário Oficial da República Federativa do Brasil.

Brasil. Ministério da Agricultura, Pecuária e Abastecimento. (2002). Instrução Normativa no 51, de 18/09/2002. Diário Oficial da República Federativa do Brasil. 
Brasil. Ministério da Agricultura, Pecuária e Abastecimento. (2011). Instrução Normativa $n^{\circ}$ 62, de 29/12/2011. Diário Oficial da República Federativa do Brasil.

Bromberg, R., Moreno, I., Zaganini, C. L., Delboni, R. R., \& Oliveira J. (2004). Isolation of bacteriocin-producing lactic acid bacteria from meat and meat products and its spectrum of inhibitory activity. Brazilian Journal of Microbiology, 35, 137-44. http://dx.doi. org/10.1590/S1517-83822004000100023

Castañeda, R., Borbonet, S., Ibarra, A., Ipar, J. L., Vásquez, A. M., Contreras, C. B., Purtschert, N., \& Alfonso, R. (2010). Quesos de América Del Sur. Buenos Aires: Albatros.

Cichoski, A. J., Cunico, C., Di Luccio, M., Zitkoski, J. L., \& Carvalho, R. T. (2008). Efeito da adição de probióticos sobre as características de queijo prato com reduzido teor de gordura fabricado com fibras e lactato de potássio. Ciência e Tecnologia de Alimentos, 28(1), 214-19. http://dx.doi.org/10.1590/S0101-20612008000100030

Clal. (2013). Mercato Lattiero Ceseario. Retrieved from http://www. clal.it/en/index.php?section=riepilogo

Cruz, A., Cadena, R., Alvaro, M., Sant'Ana, A., Oliveira, C., Faria, J., Bolini, H., \& Ferreira, M. (2013). Assessing the use of different chemometric techniques to discriminate low-fat and full-fat yogurts. LWT-Food Science and Technology, 50, 210-214. http://dx.doi. org/10.1016/j.lwt.2012.05.023

De Roest, K., \& Menghi, A. (2000). Reconsidering 'Traditional' Food: The Case of Parmigiano Reggiano Cheese. Sociologia Ruralis, 40, 439-51. http://dx.doi.org/10.1111/1467-9523.00159

European Union - EU (2006). Council Regulation (EEC) nº 510/2006. On the protection of geographical indications and designations of origin for agricultural products and foodstuffs. Official Journal of the European Union.

Gala, E., Landi, S., Solieri, L., Nocetti, M., Pulvirenti, A., \& Giudici, P. (2008). Diversity of lactic acid bacteria population in ripened Parmigiano Reggiano cheese. International Journal of Food Microbiology, 125, 347-51. PMid:18524408. http://dx.doi. org/10.1016/j.ijfoodmicro.2008.04.008

Granato, D., Calado, V., \& Jarvis, B. (2014). Observations on the use of statistical methods in food science and technology. Food Research International, 55, 137-149.

Hosken, F. S., \& Furtado, M. M. (1983). Tecnologia de fabricação de queijos. Juiz de Fora: EPAMIG.

Instituto Adolfo Lutz - IAL. (2008). Métodos Físico-Químicos para Análise de Alimentos (4. ed.). São Paulo: Instituto Adolfo Lutz.

Itália (1955). Riconoscimento delle denominazioni circa i metodi di lavorazione, caratteristiche merceologiche e zone di produzione dei formaggi (Decreto Del Presidente Della Repubblica 30 ottobre 1955, n. 1269). Gazz. Uff. N. 295 del 22 dicembre 1955.

Karoui, R., \& Baerdemaeker, J. (2007). A review of the analytical methods coupled with chemometric tools for the determination of the quality and identity of dairy products. Food Chemistry, 102(3), 621-40. http://dx.doi.org/10.1016/j.foodchem.2006.05.042

Kelly, A. L., \& Fox, P. F. (2006). Indigenous enzymes in milk: a synopsis of future research requirements. International Dairy Journal, 16(6), 707-15. http://dx.doi.org/10.1016/j.idairyj.2005.10.018

Langford, V. S., Reed, C. J., Milligan, D. B., McEwan, M. J., Barringer, S. A., \& Harper, W. J. (2012). Headspace Analysis of Italian and New Zealand Parmesan Cheeses. Journal of Food Science, 77(6), C719-C726. PMid:22591108. http://dx.doi.org/10.1111/j.17503841.2012.02730.x

Lortal, S., \& Chapot-Chartier, M. P. (2005). Role, mechanisms and control of lactic acid bacteria lysis in cheese. International Dairy Journal, 15(6-9), 857-71. http://dx.doi.org/10.1016/j. idairyj.2004.08.024
Macedo, A. C., Costa, M. L., \& Malcata, F. X. (1996). Assessment of proteolysis and lipolysis in Serra cheese: effects of axial cheese location, ripening time and lactation season. Lait, 76, 363-70. http:// dx.doi.org/10.1051/lait:1996427

Malacarne, M., Summer, A., Franceschi, P., Formaggioni, P., Pecorari, M., Panari, G., \& Mariani, P. (2009). Free fatty acid profile of Parmigiano-Reggiano cheese throughout ripening: Comparison between the inner and outer regions of the wheel. International Dairy Journal, 19, 637-41. http://dx.doi.org/10.1016/j.idairyj.2009.04.004

Monfredini, L, Settanni, L., Poznanski, E., Cavazza, A., \& Franciosi, E. (2012). The spatial distribution of bacteria in Grana-cheese during ripening. Systematic and Applied Microbiology, 35(1), 54-63. PMid:21943677. http://dx.doi.org/10.1016/j.syapm.2011.07.002

Ogunbanwo, S. T., Sanni, A. I., \& Onilude, A. A. (2003). Influence of cultural conditions on the production of bacteriocin by Lactobacillus brevis OG1. African J Biotechnol, 2(7), 179-84.

Panari, G., Mariani, P., Summer, A., Guidetti, R., \& Pecorari, M. (2003). Variazione della composizione e andamento della proteolisi del Parmigiano-Reggiano nel corso della maturazione in riferimento al profilo (centro e periferia) della forma. Scienza e Tecnica Lattiero Casearia, 54(3), 199-212.

Perry, K. S. P. (2004). Queijos: Aspectos Químicos, Bioquímicos e Microbiológicos. Química Nova, 27(2), 293-300. http://dx.doi. org/10.1590/S0100-40422004000200020

Pimentel, E. F., Dias, R. S., Ribeiro-Chua, M., \& Glória, M. B. A. (2002). Avaliação da rotulagem e da qualidade físico-química e microbiológica de queijo ralado. Ciência e Tecnologia de Alimentos, 22(3), 289-94. http://dx.doi.org/10.1590/S0101-20612002000300016

Ribeiro, J. C. B., Cardoso, C. R., Esmerino, L. A., Santos, R. D., Demiate, I. M., \& Nogueira, A. (2012). Qualidade físico-química e microbiológica do queijo parmesão ralado comercializado em Ponta Grossa, Paraná. Revista do Instituto de Laticínios "Cândido Tostes", 67(387), 21-9. http://dx.doi.org/10.5935/2238-6416.20120046

Rocha, A. M. C. N., Mota, C. C. A. R., \& Morais, A. M. M. B. (2007). Physico-chemical qualities of minimally processed carrot stored under vacuum. Journal of Foodservice, 18, 23-30. http://dx.doi. org/10.1111/j.1745-4506.2007.00043.x

Salvador, M., Camassola, M., Moschen, E., \& Zanrosso, A. V. (2001). Avaliação da qualidade microbiológica de queijo prato e parmesão ralado. Boletim do CEPPA, 19(1), 65-74

Scot Consultoria. (2013). Produção de queijos no Brasil deve ultrapassar 1,0 milhão de toneladas em 2013. Retrieved from http://www. scotconsultoria.com.br/noticias/artigos/28592/producao-dequeijos-no-brasil-deve-ultrapassar-10-milhao-de-toneladasem-2013.htm

Silva, N. D., Junqueira, V. C. A., \& Silveira, N. (2007). Manual de Métodos de Análise Microbiológica de Alimentos (3. ed.). São Paulo: Varela.

Souza, S., Cruz, A., Walter, E., Faria, J., Celeghini, R., Ferreira, M., Granato, D., \& Sant'Ana, A. (2011). Monitoring the authenticity of Brazilian UHT milk: A chemometric approach. Food Chemistry, 124, 692-695. http://dx.doi.org/10.1016/j.foodchem.2010.06.074

Trombete, F. M., Fraga, M. E., \& Saldanha, T. (2012). Avaliação da qualidade química e microbiológica de queijo parmesão ralado comercializado no Rio de Janeiro. Revista do Instituto de Laticínios "Cândido Tostes", 67(385), 11-6. http://dx.doi.org/10.5935/22386416.20120017

Zannoni, M. (2010). Evolution of the sensory characteristics of Parmigiano-Reggiano cheese to the present day. Food Quality and Preference, 21, 901-5. http://dx.doi.org/10.1016/j. foodqual.2010.01.004 